\title{
Preface to special issue (Impacts of surface ocean acidification in polar seas and globally: a field-based approach)
}

\author{
Toby Tyrrell ${ }^{1}$, Geraint A. Tarling ${ }^{2}$, Ray Leakey ${ }^{3}$, Gemma Cripps ${ }^{1}$, Sally Thorpe ${ }^{2}$, Sophie Richier ${ }^{1}$, C. \\ Mark Moore ${ }^{1}$ \\ ${ }^{1}$ Ocean and Earth Science, National Oceanography Centre Southampton, University of \\ Southampton, Southampton SO14 3ZH, UK \\ 2 British Antarctic Survey, Natural Environment Research Council, High Cross, Madingley Rd, \\ Cambridge, CB3 OET, UK \\ 3 Scottish Association for Marine Science, Dunstaffnage Marine Laboratory, Oban, Argyll, PA37 1QA, \\ UK
}

\section{Introduction}

Both ocean acidification and global warming are consequences of the rise in atmospheric $\mathrm{CO}_{2}$. Ocean acidification is not itself a consequence of global warming, but rather of the invasion of atmospheric $\mathrm{CO}_{2}$ into the ocean. Time-series of carbonate chemistry measurements in different locations around the world all document the continuous and ongoing increase in the amount of $\mathrm{CO}_{2}$ in the ocean, and the consequential accompanying decrease in surface ocean seawater $\mathrm{pH}$ at all sites over the last years (Bates et al., 2014).

The $40 \%$ rise in atmospheric $\mathrm{CO}_{2}$ levels over and above preindustrial values has led to a decrease in surface seawater $\mathrm{pH}$ of about 0.1 units, and if emissions continue to rise according to worst-case scenarios, as they have done until now, then at the end of this century (the year 2100) surface seawater $\mathrm{pH}$ may be about 0.4 units below preindustrial levels. The fundamental seawater chemistry is well understood and leads to predictions that surface seawater $\mathrm{pH}$ should decline in all oceans, with the single exception of regions where upwelling of deep waters occurs, where the recentlyupwelled surface seawater has not yet had time to exchange $\mathrm{CO}_{2}$ with the higher concentrations now in Earth's atmosphere. This expectation is borne out by the records at the time-series sites which confirm that ocean acidification is a geographically global phenomenon (Bates et al., 2014). Nevertheless, the chemical impacts of ocean acidification are not equal in all locations, since seawater carbonate chemistry is changed from a different initial baseline in different locations.

For calcifying organisms, that build their shells or skeletons out of calcium carbonate $\left(\mathrm{CaCO}_{3}\right)$, the saturation state of surface seawater with respect to calcium carbonate $(\Omega$, primarily controlled by the carbonate ion concentration) has been a major concern because it may affect their ability to build shells and skeletons and subsequently to maintain them against dissolution. For instance, both the PIC:POC (Particulate Inorganic Carbon : Particulate Organic Carbon) ratio of coccolithophores (Meyer \& Riebesell, 2015) and the dissolution of pteropod shells (Bednaršek et al., 2012) appear to be affected by the value of $\Omega$. As a result of high gas solubility associated with cold temperatures towards the poles,, there are naturally higher dissolved carbon dioxide gas concentrations and, associated with them, naturally lower carbonate ion concentrations in polar waters. These regions are, as a result, intrinsically more susceptible to becoming undersaturated with respect to calcium carbonate $(\Omega<1)$. For this reason polar waters may suffer more severe consequences of ocean acidification. The $\mathrm{pH}$ of polar waters, on the other hand, is not especially low compared to other latitudes.

The study of ocean acidification is about 15 years old: the first papers were published around about the year 2000. Much of the work into ocean acidification so far (Gattuso \& Hansson, 2011) has taken 
the form of laboratory-based studies. Although this method of inquiry is still the most frequently adopted, an increasing number of studies are now assessing likely impacts through study of the natural environment. The papers in this special issue mostly come from research following this second approach, carried out within a consortium of the UK ocean acidification (UKOA) research programme. The UKOA pelagic consortium has been looking at impacts of ocean acidification in the upper ocean, and undertook three cruises, the particular aim of which was to investigate ocean acidification impacts under as realistic conditions as possible, including through collecting in situ observations and through carrying out experiments on natural communities of organisms under natural conditions. Together these three cruises make up the largest ever coordinated campaign for investigating the impacts of ocean acidification on the surface open ocean through in situ approaches. Our consortium aims to complement the more artificial laboratory studies with research from more realistic in-situ studies. The results from the first of the three cruises, in northwest European shelf seas, were previously published in a separate special issue (http://www.biogeosciences.net/special_issue160.html). Here, in this second special issue on the consortium's work, we report results from the $2^{\text {nd }}$ and $3^{\text {rd }}$ cruises of this large consortium, alongside syntheses of data collected on all three cruises and laboratory work based on studies of organisms collected during the three cruises.

\section{Arctic cruise.}

The overall aim of the UKOA Arctic cruise was to obtain a quantitative understanding of the impact of ocean acidification on the surface ocean biology and ecosystem, and on the role of the surface ocean within the Arctic. This was achieved by undertaking in situ observations across natural carbonate chemistry gradients, and by undertaking on-deck $\mathrm{CO}_{2}$ perturbation incubations ("bioassays"), in the Atlantic sector of the Arctic between 1 June and 2 July 2012 on the RRS James Clark Ross (cruise JR271).

A total of 45 stations were sampled between the UK and Svalbard along latitudinal and longitudinal gradients crossing the North Atlantic Ocean and North, Norwegian and Greenland Seas, including ice-covered waters of the Fram and Denmark Straits (Figure 1). The stations encompassed a wide range of environmental conditions, including in temperature, ice-cover, carbonate chemistry, nutrients, productivity, and plankton composition. They included: (i) North Sea waters in which previous in situ observations and a carbonate chemistry bioassay experiment (Richier et al., 2014) had been conducted during the UKOA north-west European shelf seas cruise D366; (ii) North Atlantic waters south of Iceland characterised by relatively high coccolithophore abundance; (iii) north-south and east-west transects across Barents, Greenland and Norwegian Seas encompassing strong gradients of the carbonate system, nutrient concentration and ecosystem productivity; (iv) ice-edge waters of the Greenland Sea encompassing strong changes in the carbonate system; and (v) Svalbard fjord waters characterised by relatively high pteropod abundance.

A total of 70 CTD casts were conducted throughout the cruise and at most stations a wide range of environmental observations were undertaken on discrete water samples collected from depth profiles. Underway measurements were also conducted throughout the cruise except in ice-covered or shallow coastal waters. These included (i) continuous monitoring and discrete sampling of the research vessel's pumped sea water supply from $6 \mathrm{~m}$ depth, (ii) continuous monitoring of trace metal concentrations using a Towfish, and (iii) monitoring of zooplankton using a towed continuous plankton recorder. Five carbonate chemistry bioassay experiments were conducted using surface $(\leq 20 \mathrm{~m})$ water collected under trace-metal free conditions and incubated for up to 96 hours after increasing their $p \mathrm{CO}_{2}$ up to a maximum of $1000 \mu \mathrm{atm}$. As reported by Rees et al. (pages XXX to YYY) a number of the experiments were also performed on sub-surface communities. 
The ranges of surface water physical and chemical environmental conditions encountered during the Arctic cruise are presented in Table 1 and a full description of the physical oceanographic conditions can be found in (Cottier et al., 2014). Three major oceanographic fronts were crossed during the cruise, as revealed from continuous underway temperature and salinity measurements at $6 \mathrm{~m}$ depth: the Iceland Faroes Front, the East Greenland Polar Front, and the Polar Front in the Barents Sea (Figure 1). Temperature and salinity ranged across all stations from -1.6 to $10^{\circ} \mathrm{C}$ and $32.3-35.4$, with colder, less saline polar water located north and west of the fronts. Nine stations were located within or in close proximity to the sea-ice to the west of the East Greenland Polar front: seven in the Fram Strait and two in Demark Strait (Figure 1). The initial environmental conditions of each of the carbonate chemistry bioassay experiments differed according to location, from the relatively warm, saline waters of the North Sea $\left(\sim 11^{\circ} \mathrm{C}\right.$, salinity of 35$)$ and North Atlantic $\left(\sim 10.5^{\circ} \mathrm{C}, 35\right)$, through the cooler Atlantic-influenced waters of the southern Barents Sea $\left(\sim 6.5^{\circ} \mathrm{C}, 35\right)$ and northern Greenland Sea $\left(\sim 1.5^{\circ} \mathrm{C}, 35\right)$, to the cold, less saline Arctic-influenced ice-covered waters of the East Greenland Current in the Fram Strait $\left(\sim-1.5^{\circ} \mathrm{C}, 32.5\right)$.

Levels of $p \mathrm{CO}_{2}$ recorded in seawater during the cruise (Table 1) were always below atmospheric values, with lowest values recorded in areas of high primary productivity in the Barents Sea, western Fram Strait, and Norwegian Sea north of Iceland. Levels of $\Omega_{\text {aragonite }}$ and $\Omega_{\text {calcite }}$ in the upper $400 \mathrm{~m}$ were $>1$ at all stations with highest values corresponding to regions with high primary production (Tynan et al., this issue). Lowest $\Omega_{\text {aragonite }}$ and $\Omega_{\text {calcite }}$ and $\mathrm{pH}$ values were observed in cold, lower salinity polar surface waters associated with sea ice west of the East Greenland Polar Front in the Fram Strait (Tynan et al., this issue). Inorganic nutrient concentrations were typical for the region (Table 1).

The phytoplankton community encountered during the cruise was dominated by a mix of diatoms dinoflagelates and flagellates, as typical for the region, with variable chlorophyll-a concentrations of up to $6 \mathrm{mg} \mathrm{m}^{-3}$ (Poulton et al., this issue). A relatively diverse community of coccolithophores was observed during the cruise, as compared with that encountered in the UKOA Southern Ocean cruise (JR274). Relatively high coccolithophore concentrations $\left(>100,000 \mathrm{I}^{-1}\right)$ were recorded in the North Atlantic south of Iceland, the central Norwegian Sea, and the eastern Greenland Sea off Svalbard; but at no stations did these calcifiers dominate the phytoplankton abundance or biomass (Poulton et al. this issue). Pteropods were rare throughout the study but attained high abundances in Svalbard coastal waters (Peck et al., this issue).

<FIGURE 1 TO GO ABOUT HERE>

\section{Southern Ocean cruise.}

The third UKOA research cruise was conducted over the period from $9^{\text {th }}$ January to $12^{\text {th }}$ February 2013 aboard the RRS James Clark Ross (cruise JR274). The cruise track is shown in Figure 2, and covered a distance of $\sim 5000$ nautical miles. A total of 78 CTD casts were conducted at 50 stations. We typically occupied two stations per day, one from dawn (05:00 local time, GMT-3) to local midday and a second station, with a less extensive set of deployments, between 17:00 and 18:00 local time. In addition to the observational study, we conducted 4 biological carbonate chemistry manipulation experiments using surface waters and associated microbial communities. These incubation experiments were run for between 4 and 8 days and in which $p \mathrm{CO}_{2}$ was manipulated up to a maximum of $2000 \mu \mathrm{atm}$, and a number of additional experiments were also performed on subsurface water (Rees et al., pages XXX to YYY). 
The surface layers of the Southern Ocean have some of the lowest naturally occurring concentrations of carbonate ion in the world's oceans. The Southern Ocean research cruise was designed to sample across natural gradients in carbonate chemistry, with the aim of decoupling these gradients from other frequently co-varying variables, such as temperature and salinity. This was implemented through the attainment of four major objectives: (i) to cover the regularly sampled Drake Passage, where $\Omega_{\text {aragonite }}$ has previously been found to vary between from 1.25 to $>2$; (ii) to transect across strong gradients in $\Omega_{\text {aragonite }}$ and $\Omega_{\text {calcite }}$ along multiple N-S transects at different longitudes, covering ice edge regions and high productivity close to South Georgia, where $\mathrm{pH}$ and $\Omega_{\text {aragonite }}$ and $\Omega_{\text {calcite }}$ vary without any corresponding change in surface temperatures; (iii) to traverse a S-N (ice-edge to Polar Front) transect, sampled regularly by the British Antarctic Survey, and containing $\Omega_{\text {aragonite }}$ levels close to undersaturation at sites of natural upwelling; (iv) to enter the exceptionally cold Weddell Sea, where large-scale undersaturation is predicted to occur first in the Southern Ocean.

Accordingly, the cruise covered 5 major regions that, together, characterise some of the major contrasts in Southern Ocean environmental conditions: (i) Drake Passage, (ii) Weddell Sea ice-edge, (iii) the open-ocean sector of the Scotia Sea, (iv) South Georgia bloom region, and (v) the open Weddell Sea. These regions were spread between 4 water mass zones, the southernmost being the Weddell Sea zone (found in regions ii and v), the Antarctic Zone (found in I and iii), the Southern Zone (found in iii and iv) and the Polar Frontal Zone (found in i and iii). Regional average [SD] surface temperatures ranged between cold Weddell Sea ice-edge and open Weddell Sea sectors $\left(0.8^{\circ} \mathrm{C}[0.7]\right.$ and $0.5^{\circ} \mathrm{C}[0.4]$ respectively) to the warmer Drake Passage $\left(3.5^{\circ} \mathrm{C}[2.3]\right)$ and South Georgia $\left(3.8^{\circ} \mathrm{C}\right.$ [1.0]) sectors. Average regional salinities were relatively constant at between 33.6 and 33.9. Low salinity values were measured in areas that were in recent contact with sea ice, and higher salinity values (> 34.0) were measured in northern Drake Passage and north of the South Sandwich Islands. The lowest $\Omega_{\text {aragonite }}$ levels in the surface layers were found in the open Scotia Sea region, where they reached a minimum of 1.01. Regional average $\Omega_{\text {aragonite }}$ levels were however between 1.7 and 1.9 in all sampling regions. Surface $p \mathrm{CO}_{2}$ concentrations were lowest in the open Weddell Sea sector, where the regional average [SD] was $282 \mu$ atm [36]. While the highest average $p \mathrm{CO}_{2}$ levels were found close to South Georgia (375 $\mu \mathrm{atm}[100]$ ) values were extremely variable and were as low as 236 uatm in places. Surface $\mathrm{pH}$ was relatively constant across all regions, with a regional average of 8.1 in Drake Passage, the Weddell Sea ice-edge, the open Scotia Sea and South Georgia, and 8.2 in the open Weddell Sea.

Over a large part of its area, the Southern Ocean is considered to be a 'high nutrient, low chlorophyll (HNLC)' environment as a result of limited iron availability that constrains phytoplankton production. High levels of macronutrient availability were apparent in surface waters throughout the 5 major sampling regions (Table 1). Nitrate and phosphate concentrations were high everywhere. Silicate showed a higher degree of variability, being relatively low in the Drake Passage and South Georgia regions (regional averages of 15.9 and $13.1 \mu \mathrm{mol} \mathrm{kg}^{-1}$ respectively) but higher in the open Scotia Sea $\left(19.7 \mu \mathrm{mol} \mathrm{kg}{ }^{-1}\right)$ and very high at the ice-edge $\left(43.4 \mu \mathrm{mol} \mathrm{kg}{ }^{-1}\right)$ and in the open Weddell Sea $(65.3$ $\left.\mu \mathrm{mol} \mathrm{kg}{ }^{-1}\right)$. Siliceous diatoms dominate the phytoplankton communities of the Southern Ocean and their demands affect the availability of silicate. This was broadly seen in the inverse relationship between silicate and surface chl- $a$ levels. Regional average chl- $a$ was high at South Georgia $\left(2.8 \mu \mathrm{g} \mathrm{L}{ }^{-}\right.$ $\left.{ }^{1}\right)$ and in the open Scotia Sea $\left(4.3 \mu \mathrm{g} \mathrm{L}^{-1}\right)$, where silicate concentrations were low, and low in the open Weddell Sea $\left(0.7 \mu \mathrm{g} \mathrm{L}^{-1}\right)$, where there was a high availability of silicate. Nevertheless, both chl-a $\left(2.0 \mu \mathrm{g} \mathrm{L}^{-1}\right)$ and silicate levels were high at the ice-edge, which may be explained by the majority of chl- $a$ being contained in the smaller sized fractions (less than $2 \mu \mathrm{m}$ ), which have a lower demand for silicate.

<FIGURE 2 TO GO ABOUT HERE > 
<TABLE 1 TO GO ABOUT HERE>

\section{Papers in this special issue.}

The papers in this issue focus both on possible impacts on calcifying organisms, and also on impacts on other aspects of biogeochemical and ecosystem function that potentially could be affected by ocean acidification.

Tynan et al (pages XXX to YYY) carry out in-depth analyses of the carbonate chemistry data from both cruises in order to better understand controlling processes. Both polar areas have spatially variable $\mathrm{pH}$ and $\Omega_{\text {aragonite }}$ and $\Omega_{\text {calcite }}$ values. While $\Omega_{\text {aragonite }}$ and $\Omega_{\text {calcite }}$ were low in some regions, as expected in polar areas (for the reasons explained above), in other regions they were higher. Tynan et al. describe the differences in values and in important driving processes, improving our understanding of current and future patterns of these variables. Rickaby et al. (pages XXX to YYY) took advantage of the large numbers of strains of the coccolithophore Emiliania huxleyi that were obtained from the several global ocean areas through which the cruises passed; they subjected them to examination before the cells had had time to become too strongly adapted to artificial laboratory conditions. Through measuring the variability between strains in terms of their physiological and photosynthetic characteristics, their results shed light on within-morphotype and betweenmorphotype variability and its relation to environmental conditions. It is concluded that the in-situ cellular calcification rate is related to the natural environmental carbonate ion concentration $\left(\left[\mathrm{CO}_{3}{ }^{2-}\right.\right.$ ]) at that site. Peck et al. (pages XXX to YYY) examined the potential for dissolution of pteropod shells in undersaturated or nearly undersaturated conditions. They found that possession of an intact periostracum (organic membrane that surrounds the shell) is a key factor in maintaining a healthy shell, and only when it is breached and the exposed shell is subject to undersaturated waters will dissolution occur. Furthermore, detailed examination of shells recovered from the Greenland sea ice margin revealed that pteropods have some capacity for repair of shell damage (through synthesis of new aragonite secreted internally at sites where dissolution threatens to penetrate the full depth of the original shell).

Poulton et al. (pages XXX to YYY) found no effect of $\mathrm{CO}_{2}$ level on the proportion of the carbon fixed by phytoplankton that was released as dissolved organic carbon (DOC); DOC is an important source of energy for bacteria and the production of some forms of DOC, specifically transparent exopolymer particles (TEP), has been implicated as a potential key factor in the biogeochemical consequences of OA (Riebsell et al. 2007). Poulton et al. suggest instead that nutrients (silicic acid in particular) can play a bigger role, through their effect on the growth and nutrient stress of diatoms, who are potentially important producers of DOC. Tarling et al. (pages XXX to YYY) studied the interactions between copepods (zooplankton) and different phytoplankton groups. They found that high $\mathrm{CO}_{2}$ altered the grazing preferences of the copepods, leading them to feed more intensively on dinoflagellates, whose numbers decreased. Rees et al. (pages XXX to YYY) investigated the effect of $\mathrm{OA}$ on the production of the potent greenhouse gas nitrous oxide $\left(\mathrm{N}_{2} \mathrm{O}\right)$, which causes about 300 times more global warming per molecule than $\mathrm{CO}_{2}$. Whereas earlier work (Rees et al., 2014) had found no systematic effect of $\mathrm{OA}$ on $\mathrm{N}_{2} \mathrm{O}$ production in surface waters, where not much $\mathrm{N}_{2} \mathrm{O}$ is produced, in this study OA was found to quite strongly suppress $\mathrm{N}_{2} \mathrm{O}$ production in subsurface waters where production rates are higher.

\section{Overview of initial findings from carbonate chemistry bioassay experiments.}


The individual papers in this special issue focus on presenting detailed analysis of evidence illuminating various impacts of ocean acidification. As well as detailed analysis of OA impacts on individual organisms, parameters and biogeochemical processes, it is also of interest to try to gain a wider perspective of overall OA impacts. Or in other words it is of interest to have an overview of the likely impacts. Tables 2 and 3 present a synthesis of the results we obtained in the carbonate chemistry bioassay experiments on the Arctic (JR271; 2012 June 1 - July 2) and the Southern Ocean (JR274; 2013 January 9 -February 12) cruises (BODC DOI refs).

All experiments were set up and run according to the methods previously described for the first cruise to the NW European Shelf (Richier et al. 2014), with a few exceptions. In particular, extensive cleaning procedures and trace metal clean sampling techniques were applied in the iron-limited waters of the Southern Ocean. Briefly, before first use, bottles were filled up to the neck with detergent (1\% Decon) for 1 day followed by three rinses with de-ionised water, and then filled with $10 \% \mathrm{HCl}$ (Aristar grade) for 3 days followed by three rinses with de-ionised water. Experiments were subsequently set up inside a trace-metal-clean container, with seawater collected from three dedicated CTDs deployed successively. Biological replicates $(n=3)$ were obtained through filling each bottle of a triplicate with water from a different CTD cast. Comparison of results against those from separate iron-addition experiments (+0.2 nM DFe) showed that trace-metal cleaning techniques had been effective. All reagents for the carbonate chemistry manipulations were pre-cleaned using a Chelex ${ }^{\circledR}$ column (Sunda et al, 2005). A wider range of target $\mathrm{CO}_{2}$ values (ambient, 550, 750, 1000 and $2000 \mu \mathrm{atm})$ was also used in some experiments. Moreover, the 4-day-incubation period applied as standard during the Arctic cruise was extended up to 8 days in the Southern Ocean in order to allow further time to detect any potentially slower physiological response in these colder waters. Irradiance (100 $\mu \mathrm{mol}$ quanta. $\left.\mathrm{m}^{-2} \mathrm{~s}^{-2}\right)$ was provided by daylight simulation LED panels (Powerpax, UK) over a light-dark cycle approximating the ambient photoperiod: $24 \mathrm{~h}$ continuous light in the Arctic (except for experiment E1 with 18-6 h) and 18-6 h in the Southern Ocean.

As can be seen in the tables, a large number of different parameters were measured (processes examined) (Richier et al., 2014). For the majority of parameters measured, in the majority of experiments there were no significant detectable responses to deliberate short term severe manipulation of the carbonate system. Moreover, in the few cases where statistically significant responses were observed, they were generally inconsistent between different experiments. The only response that was nearly consistent across all experiments was the observed suppression of $\mathrm{N}_{2} \mathrm{O}$ production (Rees et al., pages XXX to YYY).

In addition to the papers in this and the previous special issue, other outcomes of the consortium's work on the cruises are being published elsewhere. Together, these papers combine to provide valuable 'ground-truthing' to ocean acidification research, leading to more robust and realistic estimates of OA impacts on the upper ocean.

\section{Acknowledgements.}

The UKOA polar research cruises could not have been undertaken without the efforts of a large number of people located in several organisations. We are grateful for the help and assistance of all those involved including: the captains, officers and the crew of the RRS James Clark Ross on JR271 and JR274; the scientists and technical support staff on both cruises; the staff of the British Antarctic Survey, Cambridge, National Marine Facilities, Southampton, and the Scottish Association for Marine Science, Oban. We are grateful to Finlo Cottier, Phil Hwang and Lewis Drysdale for assistance with physical oceanographic analyses. We are also grateful to the UK Natural Environment Research Council (NERC), the UK Department of Environment, Food and Rural Affairs (Defra), and the UK 
Department of Energy and Climate Change (DECC) for funding the research cruise via the UK Ocean Acidification research programme (Lead NERC Grant: NE/H017348/1), and to the Danish, Icelandic and Norwegian diplomatic authorities for granting permission to travel and work in Greenland, Iceland and Svalbard coastal and offshore waters. 


\section{References.}

Bates, N., Astor, Y., Church, M., Currie, K., Dore, J., Gonaález-Dávila, M., Lorenzoni, L., Muller-Karger, F., Olafsson, J. \& Santa-Casiano, M. (2014) A time-series view of changing ocean chemistry due to ocean uptake of anthropogenic $\mathrm{CO}_{2}$ and ocean acidification. Oceanography 27(1): 126-141.

Bednaršek, N., Tarling, G. A., Bakker, D. C. E., Fielding, S., Jones, E. M., Venables, H. J., Ward, P., Kuzirian, A., Lézé, B., Feely, R. A. \& Murphy, E. J. (2012). Extensive dissolution of live pteropods in the Southern Ocean. Nature Geoscience, 5(12), 881-885.

Cottier, F., Hwang P., Drysdale L. (2014) JR271 Physical Oceanography Analysis for Ocean Acidification Cruise. SAMS Internal report 290, pp. 31.

Donlon, C.J., Martin, M., Stark, J., Roberts-Jones, J., Fiedler, E., Wimmer, W. (2012) The Operational Sea Surface Temperature and Sea Ice Analysis (OSTIA) system. Remote Sens. Environ., 116, 140-158. doi: 10.1016/J.Rse.2010.10.017

Gattuso, J.-P. \& Hansson, L. (eds) (2011) Ocean Acidification. Oxford University Press, 2011.

Meyer, J., \& Riebesell, U. (2015). Reviews and Syntheses: Responses of coccolithophores to ocean acidification: a meta-analysis. Biogeosciences, 12, 1671-1682.

Orsi, A.H., Whitworth, T. \& Nowlin, W.D. (1995) On the meridional extent and fronts of the Antarctic Circumpolar Current. Deep-Sea Research, 42: 641-673.

Pierrot, D., Lewis, E., Wallace, D.W.R. (2006) CO2SYS MS Excel Program Developed for CO2 System Calculations. ORNL/ CDIAC-105. Carbon Dioxide Information Analysis Center, Oak Ridge National Laboratory, US Department of Energy, Oak Ridge, TN.

Richier, S., Achterberg, E.P., Dumousseaud, C., Poulton, A.J., Suggett, D.J., Tyrrell, T., Zubkov, M.V. \& Moore, C.M. (2014) Phytoplankton responses and associated carbon cycling during shipboard carbonate chemistry manipulation experiments conducted around Northwest European shelf seas. Biogeosciences, 11, 4733-4752.

Spreen, G., Kaleschke, L. and Heygster, G. (2008) Sea ice remote sensing using AMSR-E 89-GHz channels, J. Geophys. Res., 113, C02S03, doi:10.1029/2005JC003384.

Sunda, W.G., Price N.M. \& Morel F.M.M. (2005) Trace metal ion buffers and their use in culture studies. In: Algal Culturing Techniques. Anderson, R.A., Elsevier: 35-65.

Thorpe, S.E., Heywood, K.J., Brandon, M.A. \& Stevens, D.P. (2002) Variability of the southern Antarctic Circumpolar Current front north of South Georgia. Journal of Marine Systems, 37: 87-105. 


\begin{tabular}{|c|c|c|}
\hline & Arctic Cruise & Southern Ocean Cruise \\
\hline Temperature $\left({ }^{\circ} \mathrm{C}\right)$ & $-1.6-10.8$ & $-1.5-5.5$ \\
\hline Salinity & $32.3-35.4$ & $32.7-34.1$ \\
\hline Seafloor depth (m) & $20-2500$ & $253-5803$ \\
\hline $\operatorname{MLD}(\mathrm{m})$ & 6- 57 & $7-75$ \\
\hline $\mathrm{Chl}-a\left(\mathrm{mg} \mathrm{m}^{-3}\right)$ & $0-6$ & $0.2-18$ \\
\hline $\mathrm{NH}_{4}^{+}\left(\mu \mathrm{mol} \mathrm{L}{ }^{-1}\right)$ & $0.001-2.03$ & $0.02-2.06$ \\
\hline $\mathrm{NO}_{3}+\mathrm{NO}_{2}\left(\mu \mathrm{mol} \mathrm{L}^{-1}\right)$ & $0-9.82$ & $9.14-28.79$ \\
\hline $\mathrm{PO}_{4}{ }^{3-}\left(\mu \mathrm{mol} \mathrm{L}{ }^{-1}\right)$ & $0.04-1.05$ & $0.45-1.94$ \\
\hline $\mathrm{Si}(\mathrm{OH})_{4}\left(\mu \mathrm{mol} \mathrm{L}^{-1}\right)$ & $1-15$ & $4-85$ \\
\hline$A_{T}\left(\mu \mathrm{mol} \mathrm{kg}^{-1}\right)$ & $2229-2350$ & $2199-2350$ \\
\hline $\left.\operatorname{DIC}(\mu \mathrm{mol} \mathrm{kg})^{-1}\right)$ & $2032-2143$ & $2062-2171$ \\
\hline pH (total scale) ${ }^{\dagger}$ & $8.06-8.46$ & $7.92-8.26$ \\
\hline$p \mathrm{CO}_{2}(\mu \mathrm{atm})^{\dagger}$ & $132-367$ & $222-520$ \\
\hline $\mathrm{CO}_{2}(\mu \mathrm{mol} \mathrm{kg})^{-1}$ & $8.2-23.3$ & $11.8-31.7$ \\
\hline $\mathrm{HCO}_{3}(\mu \mathrm{mol} \mathrm{kg})^{-1}$ & $1815-2011$ & $1887-2071$ \\
\hline $\mathrm{CO}_{3}(\mu \mathrm{mol} \mathrm{kg})^{-1}$ & $88-211$ & $71-167$ \\
\hline$\Omega_{\text {Calcite }}{ }^{+}$ & $2.1-5.0$ & $1.7-4.0$ \\
\hline$\Omega_{\text {Aragontite }}{ }^{+}$ & $1.3-3.2$ & $1.1-2.5$ \\
\hline
\end{tabular}

Table 1: The ranges of surface water environmental conditions encountered, in both the Arctic and Southern Ocean cruises. The ranges are the minimum to maximum of individual measurements, not of regional averages. ${ }^{\dagger}$ denotes carbonate chemistry parameters that were calculated (using CO2SYS; Pierrot et al, 2006) rather than directly measured. 


\begin{tabular}{|c|c|c|c|c|c|c|c|c|c|c|}
\hline & \multirow{2}{*}{\multicolumn{2}{|c|}{$\begin{array}{l}\text { Bioassay } 1 \\
\text { North Sea }\end{array}$}} & \multicolumn{2}{|c|}{ Bioassay 2} & \multicolumn{2}{|c|}{ Bioassay 3} & \multicolumn{2}{|c|}{ Bioassay 4} & \multicolumn{2}{|c|}{ Bioassay 5} \\
\hline & & & Nor & ntic & Gre & & & & & \\
\hline & $\mathrm{T}_{1}$ & $\mathrm{~T}_{2}$ & $\mathrm{~T}_{1}$ & $\mathrm{~T}_{2}$ & $\mathrm{~T}_{1}$ & $\mathrm{~T}_{2}$ & $\mathrm{~T}_{1}$ & $\mathrm{~T}_{2}$ & $\mathrm{~T}_{1}$ & $\mathrm{~T}_{2}$ \\
\hline Total Chl-a & II & - & 仓 & - & - & $\sqrt{2}$ & - & - & 介 & - \\
\hline 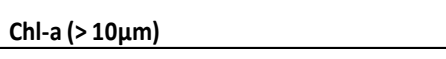 & - & - & - & - & - & - & $\sqrt{2}$ & - & - & - \\
\hline Diatom Abundance & - & - & - & - & - & - & - & - & - & - \\
\hline Dinoflagellate Abundance & - & - & - & - & - & - & - & - & - & - \\
\hline Ciliate Abundance & - & - & - & - & - & - & - & - & - & - \\
\hline Flagellate Abundance & - & - & - & - & - & - & - & - & - & - \\
\hline Heterotrophic Nanoflagellate Abundance & $\sqrt{2}$ & - & - & - & - & $\sqrt{1}$ & - & $\sqrt{2}$ & - & - \\
\hline Phototrophic Nanoflagellate Abundance & 仓 & - & - & - & 수 & 1 & - & - & - & - \\
\hline Photosynthetic Efficiency & - & - & - & - & - & - & $\sqrt{2}$ & - & - & - \\
\hline Bacterial Abundance & 介 & 个 & - & - & 个 & 个 & - & - & - & - \\
\hline Low DNA Bacteria & $\sqrt{1}$ & 介 & - & - & - & - & - & - & - & 仓 \\
\hline Bacterial Production & $\boldsymbol{1}$ & - & - & - & - & 仓 & - & - & - & - \\
\hline Bacterial Uptake & 1 & - & - & - & - & 仓 & - & - & - & - \\
\hline Calcite Production & 个 & - & - & $\sqrt{1}$ & - & - & - & - & ND & ND \\
\hline Primary Production & - & - & - & - & - & - & - & - & ND & ND \\
\hline Primary Production $(>10 \mu \mathrm{m})$ & $\sqrt{1}$ & 个 & - & - & - & - & $\sqrt{2}$ & - & ND & ND \\
\hline Dimethyl Sulfide & 全 & - & - & - & - & - & - & 全 & - & - \\
\hline Dimethylsulfoniopropionate & 介 & $\sqrt{2}$ & - & - & - & - & - & - & - & - \\
\hline Dissolved Organic Carbon & ND & ND & - & - & - & - & - & - & - & - \\
\hline Particulate Organic Phosphorus & $\sqrt{ }$ & - & 介 & - & - & - & - & - & 介 & - \\
\hline Biogenic Silica & - & - & - & - & - & - & - & - & - & - \\
\hline Nitrous Oxide & - & - & - & - & - & - & - & - & - & - \\
\hline *Nitrous Oxide & $\eta$ & $\sqrt{2}$ & $v$ & - & $v$ & - & $v$ & - & $\nabla$ & - \\
\hline Nitrate & - & - & - & - & - & - & - & - & - & - \\
\hline
\end{tabular}

Table 2: Response of surface water parameters to acidified conditions at two sampling points ( $T_{1}=2$ days; $T_{2}=4$ days) during the onboard bioassay experiments in the Arctic Ocean. Arrows represent significant increase (red) and decrease (blue) of the parameters in the acidified treatments. Dashes represent a lack of significant differences in any treatments (compared to the controls at ambient $\left.p \mathrm{CO}_{2}\right)$. Filled arrows represent significant differences in all elevated $p \mathrm{CO}_{2}$ treatments (550- $1000 \mu \mathrm{atm})$, whilst open arrows represent significant differences found in one or more but not all $p \mathrm{CO}_{2}$ treatments. ND represents no data. * denotes response of sub-surface samples to acidification. 


\begin{tabular}{|c|c|c|c|c|c|c|c|c|}
\hline & \multicolumn{2}{|c|}{ Bioassay 1} & \multicolumn{2}{|c|}{ Bioassay 2} & \multicolumn{2}{|c|}{ Bioassay 3} & \multicolumn{2}{|c|}{ Bioassay 4} \\
\hline & \multicolumn{2}{|c|}{ Mid Drakes Passage } & \multicolumn{2}{|c|}{ Ice- edge SW of Orkney } & \multicolumn{2}{|c|}{ North of South Georgia } & \multicolumn{2}{|c|}{ East of S. Sandwich Island } \\
\hline & $\mathrm{T}_{1}$ & $\mathrm{~T}_{2}$ & $\mathrm{~T}_{1}$ & $\mathrm{~T}_{2}$ & $\mathrm{~T}_{1}$ & $\mathrm{~T}_{2}$ & $\mathrm{~T}_{1}$ & $\mathrm{~T}_{2}$ \\
\hline Total Chl-a & - & - & - & - & - & 个 & - & - \\
\hline Chl-a $(>10 \mu \mathrm{m})$ & - & - & - & - & - & - & 仓 & 介 \\
\hline Diatom Abundance $^{+}$ & - & - & - & - & - & - & - & - \\
\hline Dinoflagellate Abundance $^{+}$ & - & - & - & - & - & - & - & - \\
\hline Ciliate Abundance $^{\dagger}$ & - & - & - & - & - & - & - & - \\
\hline Flagellate Abundance $^{+}$ & - & - & - & - & - & - & - & - \\
\hline Heterotrophic Nanoflagellate Abundance & - & - & - & - & - & - & $\sqrt{n}$ & - \\
\hline Phototrophic Nanoflagellate Abundance & - & - & - & - & - & 介 & - & - \\
\hline Photosynthetic Efficiency & - & - & - & - & $\sqrt{1}$ & 个 & $\boldsymbol{1}$ & - \\
\hline Total bacteria & - & - & - & - & 个 & $\uparrow$ & $\boldsymbol{1}$ & $\boldsymbol{1}$ \\
\hline High Nucleic Acid Bacteria & - & - & $\boldsymbol{\Lambda}$ & - & 个 & $\uparrow$ & 1 & 1 \\
\hline Low Nucleic Acid Bacteria & 1 & - & - & - & - & 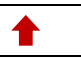 & 个 & 1 \\
\hline Calcite Production & - & - & - & - & $\sqrt{n}$ & - & - & - \\
\hline Primary Production & - & - & - & - & $\sqrt{n}$ & $\sqrt{n}$ & - & - \\
\hline Primary Production $(>10 \mu \mathrm{m})$ & - & - & - & - & $\sqrt{7}$ & - & $\sqrt{n}$ & $\sqrt{1}$ \\
\hline Dimethyl Sulfide & - & - & - & - & $\sqrt{5}$ & - & $\sqrt{7}$ & - \\
\hline Dimethylsulfoniopropionate & - & - & - & - & $\sqrt{1}$ & $\sqrt{n}$ & - & 企 \\
\hline Dimethylsulfoniopropionate (particulate) & - & - & - & - & In & $\sqrt{n}$ & - & 个 \\
\hline Particulate Organic Carbon & ND & ND & - & - & - & - & - & 全 \\
\hline Particulate Organic Nitrogen & ND & ND & - & - & $\sqrt{n}$ & - & - & 介 \\
\hline Particulate Organic Phosphorus & ND & ND & - & 1 & - & 艺 & - & 企 \\
\hline Biogenic Silica & - & - & - & - & - & - & - & 个 \\
\hline Nitrous Oxide* & ND & ND & ND & ND & 7 & $\sqrt{2}$ & II & $\sqrt{2}$ \\
\hline Nitrate & - & $\uparrow$ & - & 1 & $\sqrt{1}$ & 企 & - & 介 \\
\hline
\end{tabular}

Table 3: Response of surface water parameters to acidified conditions at two sampling points $\left(T_{1}=2-4\right.$ days; $T_{2}=4-8$ days; $\dagger=$ different sampling time points across the bioassays) during the onboard bioassay experiments in the Southern Ocean. Arrows represent significant increase (red) and decrease (blue) of the parameters in the acidified treatments. Dashes represent a lack of significant differences in any treatments (compared to the controls at ambient $p \mathrm{CO}_{2}$ ). Filled arrows represent significant differences in all elevated $p \mathrm{CO}_{2}$ treatments (550- $2000 \mu$ atm), whilst open arrows represent significant differences found in one or more but not all $p \mathrm{CO}_{2}$ treatments. ND represents no data. ${ }^{*}$ denotes response of sub-surface samples to acidification. 


\section{Figure Legends}

Figure 1: Track followed by the cruise to the Arctic Ocean (JR271), superimposed on a bathymetric map. Also shown is land including ice sheets (green), locations of $>15 \%$ sea-ice on 18th of June, the mid-point of the cruise (white), locations of CTD stations (yellow circles) and locations of bioassays (yellow stars). Sea-ice extent was taken from the OSTIA analysis (http://ghrsstpp.metoffice.com/pages/latest analysis/ostia.html) (Donlon et al., 2012).

Figure 2: Track followed by the Southern Ocean (JR274), superimposed on a bathymetric map. Also shown is land including ice sheets (green), locations of $>15 \%$ sea-ice on 26th of January, the midpoint of the cruise (white), average positions of fronts (Subantarctic Front in pink, Polar Front in red, Southern Antarctic Circumpolar Current Front in blue and Southern Boundary in black), locations of CTD stations (yellow circles) and locations of bioassays (yellow stars). Sea-ice extent was taken from the OSTIA analysis (http://ghrsst-pp.metoffice.com/pages/latest analysis/ostia.html) (Donlon et al., 2012). Positions of fronts were taken from (Orsi, 1995) and (Thorpe et al.,, 2002). 


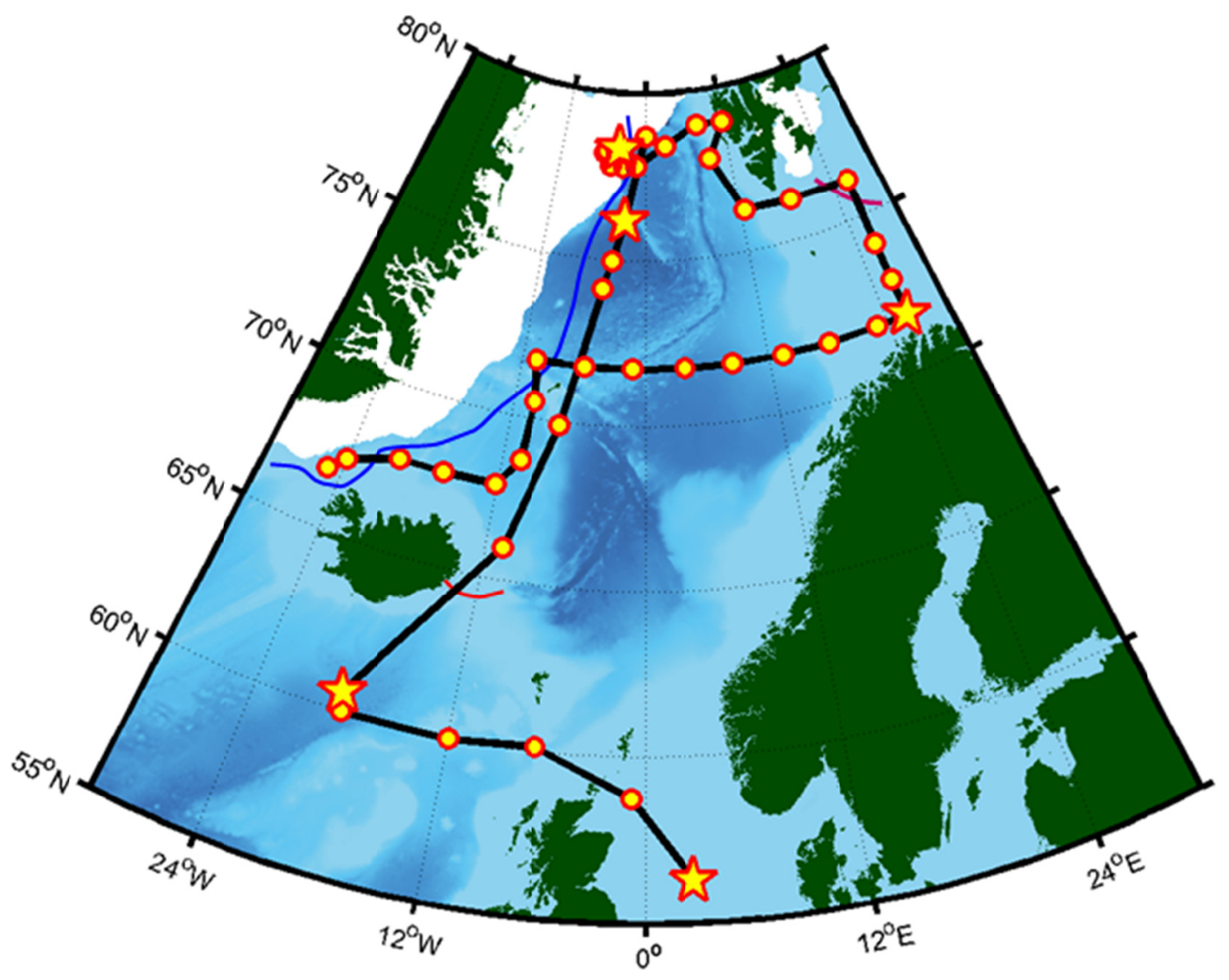

Figure 1: Track followed by the cruise to the Arctic Ocean (JR271), superimposed on a bathymetric map. Also shown is land including ice sheets (green), locations of $>15 \%$ sea-ice on 18th of June, the mid-point of the cruise (white), approximate positions of fronts (Polar Front in pink, Iceland Faroes Front in red, and East Greenland Front in blue), locations of CTD stations (yellow circles) and locations of bioassays (yellow stars). Sea-ice extent was taken from the OSTIA analysis (http://ghrsstpp.metoffice.com/pages/latest analysis/ostia.html) (Donlon et al., 2012). 


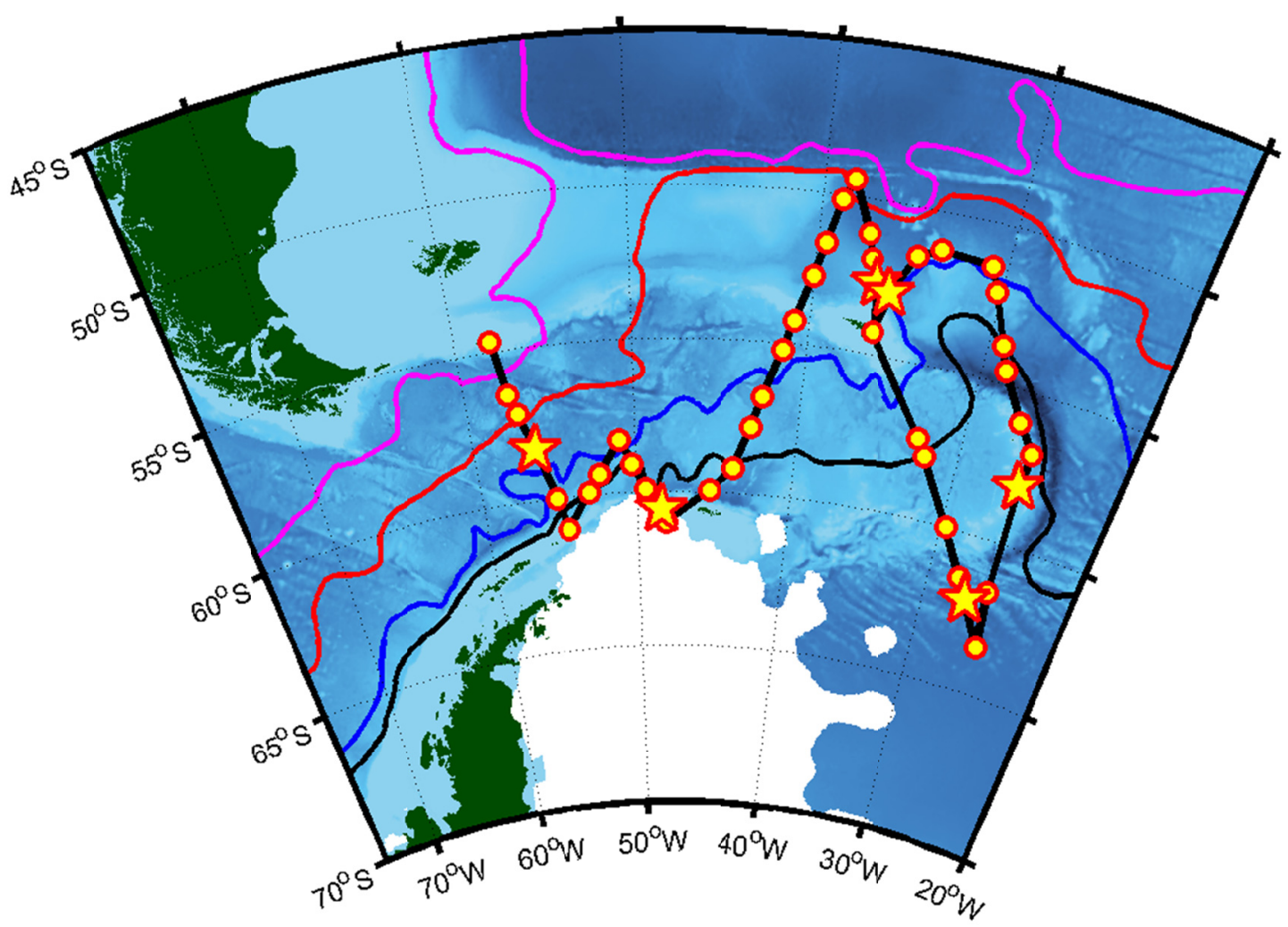

Figure 2: Track followed by the Southern Ocean cruise (JR274), superimposed on a bathymetric map. Also shown is land including ice sheets (green), locations of $>15 \%$ sea-ice on 26th of January, the mid-point of the cruise (white), average positions of fronts (Subantarctic Front in pink, Polar Front in red, Southern Antarctic Circumpolar Current Front in blue and Southern Boundary in black), locations of CTD stations (yellow circles) and locations of bioassays (yellow stars). Sea-ice extent was taken from the OSTIA analysis (http://ghrsst-pp.metoffice.com/pages/latest analysis/ostia.html) (Donlon et al., 2012). Positions of fronts were taken from (Orsi, 1995) and (Thorpe et al., 2002). 